\title{
MARJAN (CORAL) FOR CONTAINMENT OF COVID-19 IN UNANI MEDICINE
}

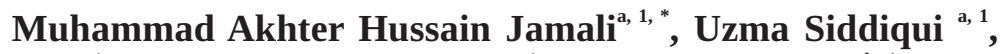 \\ Mohd Amir ${ }^{\text {a, } 1}$, Shakeeb Ahmad Khan ${ }^{\mathrm{a}, 1}$, Md Manzar Alam, ${ }^{\mathrm{b}, 1}$, Mustehasan ${ }^{\mathrm{c}, 1}$ \\ ${ }^{a}$ Regional Research Centre (Unani), CCRUM, S. M. Dev Civil Hospital, Silchar, Cachar, (Assam)-788001, India \\ ${ }^{b}$ Regional Research Institute of Unani Medicine, CCRUM, Patna-800008, Bihar, India \\ 'Central Council for Research in Unani Medicine (CCRUM), \\ 61-65 Institutional Area, Janakpuri, New Delhi-110058, India
}

\section{Review Paper}

Received: 05.10.2021

Revised: 15.10.2021

Accepted: 25.10.2021

\section{ABSTRACT}

COVID-19 pandemic has been propagating with high amplitude and paralyzing the healthcare system with powerful tentacles. Nonavailability of specific drug against the Corona virus disease-19 turned the world attention towards finding ways to strengthen the host defense, the most effective measure of containment of spread of pandemic. Coral has potential to be used as an immunomodulator for this purpose. This article is aimed to provide an overview of prophylactic role of coral in relevance with current pandemic. A manual literature survey of classical Unani texts was conducted to collect the information on Marjan (coral). In addition, electronic databases such as PubMed, Google Scholar and Science Direct were searched to identify researches conducted on Coral as well as to obtain recent information about COVID-19 outbreak. The keywords used were "Marjā̄", "Coral”, "Containment”, “COVID-19", and "Unani Medicine”. The literature review shows that Unani philosophers have emphasized the role of coral as source of calcium in enhancing the immunity of the host linking their action on vital organ. Marjan̄ (coral) as described in classical Unani text seems to be much relevant in today's context. Arguably calcium is the most important mineral in enhancing the immunity to strengthen the host defense. Hence it is our opinion; it is worth assessing this animal origin drug may be used as prophylactic agent in current outbreak.

No. of Pages: 9

No. of Tables: 2

No. of Figures: 1

References: 48

Keywords: Marjān, Coral, Containment, COVID-19, Unani Medicine.

\section{INTRODUCTION}

COVID-19 has emerged as the most dangerous pandemic threat throughout the globe since its outbreak during December 2019 (1). Rapidly spreading outbreak of COVID19 when involved 26 countries then WHO declared a public health emergency of international concern on $30^{\text {th }}$ January, 2020 (2). As of $28^{\text {th }}$ July 2021, the World Health Organization (WHO) has reported 1, 95,266,156 confirmed cases and
4,180,161 deaths worldwide (3) and Government of India has reported 3, 15,28,114 confirmed cases and 4,22,662 deaths in India (4). According to the Unani treatise, the putrefied changes occurring in air, water, soil or environment lead to putrefaction in the humors of the body. When this abnormal changes affect large part of the population at particular time range, it is known as Wabā' 'Umūmī (epidemic) $(5,6,7)$. When Jawhär (constituents) of the air is deviated from

*Corresponding author: mahjamaali@gmail.com 
normal range, it is known as epidemic air. The factors which cause deviation in the normal range of the air include seasonal variation, setting and rising of the stars and proximity and distality from the sun, Riyah (air), variation in towns and Bukhārāt (vapours).The healthy state or disease condition is under the influence of Mizāj Tabī 'Badani (Normal body temperament) and the later is under the strong influence of air. The same air may be beneficial to someone and harmful to others (8). Unani scholars considered certain climatic changes as the predisposing factors for the occurrence of an epidemic (5, 9,). In this regard, Hippocrates (460-370 BC) opined that hot and moist air is conducive to Ufūnat (infection). Al-Rāzī (865-925 AD) mentioned that $B \bar{a} d-i-J u n u \overline{b i}$ (southern wind) is associated with Wabā and is notoriously known to flare up infections. In his book, Kitāb al-Hāwi fi 'l Tibb, he specifies that the changes in the air increase during those summers which are afflicted by rainfall and cloudy weather, wherein Bād-i-Junūbi (southern wind) blows or in areas where it is trapped (5). Clinical pictures delineated by Unani scholars are as under of low grade fever, fatigue, dry cough, increased thirst, increased respiratory rate, dyspnoea, and halitosis. If a person develops bad breath, it indicates that infection has reached to cardiac tissues (6, 10). The clinical features of an infected person are strikingly similar to epidemics such as COVID-19. Due to lack of clinically proven prophylactic and therapeutic strategy, COVID-19 is surging inspite of worldwide efforts (11). This turned world attention towards strengthening the body defense force against disease causing agents (12). In order to treat the currently untreatable or to discover more efficient treatment modalities, all options and potential sources must be explored so that we can provide the best care to the patients, that is, proceed from forest and ocean ecosystem through the laboratory to the bedside (13). Marine natural products have now been acknowledged as most important source of bioactive substances and drug leads (14). Coral are the skeleton of minute marine organisms belonging to phylum Cnidaria (Coelentrata) of animal kingdom (15). Though they are tiny creations, their ability to secrete calcium carbonate $\left(\mathrm{CaCO}_{3}\right)$ within their tiny cells has given rise to a peculiar type of landform (16). It is available in two forms viz. root like structure Bekh-i- Marjañ and slender branch like structure Shakh-i-Marjañ. In the market root, is cheaper than branch and has higher \% of calcium $(17,18)$.

Over the last few years, the use and exploitation of invertebrate immune system has been pursued, most notably their humoral products to determine what effects their complex molecules exert on human, specifically their potential for therapeutic application. This endeavor called bioprospecting is an emerging necessity for biomedical research (13). It provides an opportunity to revisit the wisdom of traditional system of medicine for addressing the challenges of COVID-19 pandemic through improved immunity in combination with the proposed advisories by Government authorities for hand hygiene, respiratory hygiene, physical distancing and the use of personal protective equipments. Consequently it becomes logical to explore the literature of Unani system of Medicine understanding the challenge (19). Hence the authors have attempted to highlight the knowledge and practice of Coral in Unani medicine in the current pandemic that might be assessed as prophylactic measure.

\section{MATERIALSAND METHODS}

A manual literature survey of classical Unani texts was conducted to collect the information available on Marjan (coral) and its relevant action as immunomodulator. In addition, a comprehensive search of electronic databases such as PubMed, Google Scholar and Science Direct was carried out to identify experimental and clinical studies conducted on drugs mentioned in the literature as well as to obtain the recent information about COVID-19. For electronic databases search, medical subject headings (MeSH) and the other relevant term to the topic were used as major constructs to build a search strategy. The MeSH or other relevant terms are related to Unani Medicine, Epidemic, Prophylaxis, containment and COVID-19 constructs. To combine these, Boolean Operators “AND" and "OR" were used appropriately. The keywords used were "Marjān", "Coral”, “Containment” and "COVID-19”, "Unani Medicine”. Time restriction was not made to extract the most useful information.

\section{Coral in Unani Medicine}

Unani system of medicine is an ancient system being practiced since last 2500 years. It was originated in Greece (20). It is based on concept of Tabī 'at (Medicatrix Naturae), Akhlāt (Humours) and Mizāj (Temperament) put forward by Buqrat (Hippocrates, 460-370BC). It has holistic approach in preservation of health, alleviation of disease and preparation of medicine. The system focuses on Asbāb Sitta Darūriyya (six essentials) for preservation of health and prevention of disease. For treatment of the disease, the system uses three modes of treatment viz. 'Iläj bi'l-Tadbir wa -Ghidhā' (Regimenal and Dietotherapy), 'Ilāj bi'l-Dawā' (pharmacotherapy) and 'Ilāj bi'l-Yad (Surgery) (21). In pharmacotherapy, 90\% source drugs are herbal. The rest comprises of animal (4-5\%) and mineral (5-6\%) origin (22). In animal origin medicine, the diversity is of broad spectrum in context of morphology, habitat, texture and cost. It includes from tiny ants to giant elephant, flying birds in the sky to swimming whales in the ocean, soft silkworm to hard coral and from cheap wax to costly Amber. Generally marine animal origin drugs are costly but very effective due to 
similarity with Mizāj-i-Insaniyyah (human temperament). For many decades there has been advocacy for the use of calcium supplements in prophylaxis. Several preparations of calcium supplements are available commercially, and because of their various rates of disintegration in-vitro and dissolution characteristics, it has been suggested that calcium absorption from different preparations can vary widely. Narayanan et al found that the bioavailability of a single dose of coral derived calcium carbonate was greater than that of a single dose of non-coral calcium carbonate and calcium citrate malate in healthy, adult, human volunteers (23). Unani scholars have given very elaborative descriptions of coral (Collarium rubrum) including its vernacular name, temperament, habitat, pharmacological action and therapeutic uses, important formulations, method of application. Chemical constituent has been added by modern scientists.
1. Vernacular Name: Coral in Unani texts is described as Bekh-i-Marjā̄, Shakh-i-Marjān, Marjān and Busd Ahmar, Praval, Moonga (24).

2. Temperament: Its temperament is Cold $1^{\circ}$ and Dry $2^{\circ}$ $(25,26)$. All the forms of Marjan are dry in $3^{0}(27)$.

3. Habitats: It is under phylum Cnidaria also called Coelentrata having marine habitat (Jordan and Verma, 1999). It is mainly found in Bahr al Kahil (the Pacific Ocean) and Bahr al Hind (the Indian Ocean) (Leong, 1995).

4. Pharmacological actions and therapeutic uses of Marjā̄

Marjān has been found to exhibits diverse pharmacological actions on a visible range of ailments. Unani philosophers have described its action exclusively in their treatises (Table-1).

Table 1: Pharmacological actions and therapeutic uses of Marjān.

\begin{tabular}{|c|c|c|c|}
\hline S No. & Pharmacological Action & Therapeutic Uses & References \\
\hline 1. & $\begin{array}{l}\text { Mufarrị wa Muqawwiyāt-i Qalb } \\
\text { (exhilarant and Cardiac tonic) }\end{array}$ & $\begin{array}{l}\text { Khafaqān (palpipation), Dưf al-Qalb (cardiac } \\
\text { insufficiencies), Wahshat wa Karb, Waswās (Insanity) }\end{array}$ & $(24,28)$ \\
\hline 2. & Qābiḍ (retentive) & $\begin{array}{l}D u \text { 'f }-i-M i \text { 'da (weakness of stomach), Du 'f al-Ishtihā } \\
\text { (loss of appetite), Nafakh-i-Shikam (flatulence) }\end{array}$ & $(17,24)$ \\
\hline 3. & Hābis-i-Dam (Hemostyptic) & $\begin{array}{l}\text { Ishal Damwī (malena), Bawāsīr (heamorrhoids) and } \\
\text { Sayalan-al-Rahim (leucorrhoea) }\end{array}$ & $(24,28)$ \\
\hline 4. & Mujaffif (Desiccant) & $\begin{array}{l}\text { Suāl Ratab (productive cough), Diq al-Nafas } \\
\text { (bronchial asthma) }\end{array}$ & $(24,28)$ \\
\hline 5. & Muqawwi ada-i-Raisa & $\begin{array}{l}D u \text { 'f al-Dimāgh (Cerebrasthenia) and } \\
D u \text { 'f } f-i-A m \text { (general weakness) }\end{array}$ & $(24,28)$ \\
\hline 6. & Tiryāq (antidote) & Antidote & $(24,28)$ \\
\hline 7. & Jāli (detergent) & $\begin{array}{l}\text { Qurūḥ (wound) as Dharū'r (Dusting powder) } \\
\text { Waja al Asnan (toothache) as Sanūn (Tooth powder), } \\
\text { Amrāọ al- 'Ayn (eye Diseases) as Surma, } \\
\text { Waja al-Udhun (Earache) as ear drops with } \\
\text { Roghan Balsan }\end{array}$ & $(24,28)$ \\
\hline
\end{tabular}

\section{Important compound formulations}

Compound formulations of Marjān have been found in broad spectrum eg. Kushta, Dawā', Mufarrị̣, Kuḥl, Ear drops, Maḥlūl, Khamìra, Qurș, etc. Its purpose is to enhance the potential of drug, facilitate the administration of drug up to target organ, make the odor pleasant etc. A list of compound formulations is as under: (table-2) 
Table 2: Important compound formulations.

\begin{tabular}{|c|c|c|c|c|c|}
\hline S. $\mathbf{N}$. & Formulations & Therapeutic uses & Doses & $\begin{array}{c}\text { Mode of } \\
\text { administration }\end{array}$ & Reference \\
\hline 1. & Dawā' al-Misk Barid Sada & $\begin{array}{l}\text { Khafaqān (Palpitation), Wahshat } \\
\text { (Insanity), Strengthens heart, brain and } \\
\text { Rūh, Regulates Temperature of the heart }\end{array}$ & $5-10 \mathrm{gm}$ & $\begin{array}{l}\text { Orally with } 75 \mathrm{ml} \\
\text { 'Arq 'Gā'ozabān/35 ml } \\
\text { Arq Bedmushk/20 ml } \\
\text { Sharbat Anār } \\
\text { Shirin/ water }\end{array}$ & (29) \\
\hline 2. & $\begin{array}{l}\text { Dawā' al-Misk Barid } \\
\text { Jawahārwali }\end{array}$ & $\begin{array}{l}\text { Khafaqān (Palpitation), Wahshat (Insanity), } \\
\text { Strengthens Heart, brain and Rūh, } \\
\text { Regulates Temperature of the heart }\end{array}$ & $3-5 \mathrm{gm}$ & $\begin{array}{l}\text { Orally with } 75 \mathrm{ml} \text { 'Arq } \\
\text { 'Gā'ozabān/35 ml Arq } \\
\text { Bedmushk/ } 20 \mathrm{ml} \\
\text { Sharbat Anār } \\
\text { Shirin/ water }\end{array}$ & (29) \\
\hline 3. & Dawā' al-Misk Hārr Sada & $\begin{array}{l}\text { Strengthens heart, brain and Rūh, } \\
\text { Relieves Khafaqān (Palpitation), Wahshat } \\
\text { (Insanity) and Mālankhūliya (Melancholia), } \\
\text { Amrāọ-i- Balghamiyya (cold Phlegmatic } \\
\text { disorders such as Fālij (hemiplegia), } \\
\text { Laqwa (Bell's Palsy), Istirkhā' (atony or } \\
\text { flaccidity), Kuzāz (Tetanus) etc, } \\
\text { Strengthens stomach }\end{array}$ & $3.5 \mathrm{gm}$ & $\begin{array}{l}\text { Orally with } 75 \mathrm{ml} \\
\text { 'Arq 'Gā'ozabān/ } 35 \mathrm{ml} \\
\text { 'Arq Bedmushk/ } 20 \mathrm{ml} \\
\text { Sharbat Anār } \\
\text { Shirin/ water }\end{array}$ & (29) \\
\hline 4. & $\begin{array}{l}\text { Dawā' al-Misk Hārr } \\
\text { Jawahārwali }\end{array}$ & Same as above with stronger efficacy & $3-5 \mathrm{gm}$ & $\begin{array}{l}\text { Orally with } 75 \mathrm{ml} \\
\text { 'Arq 'Gā'ozabān } / 35 \mathrm{ml} \\
\text { Arq Bedmushk/ } 20 \mathrm{ml} \\
\text { Sharrbat Anār Shirin/ } \\
\text { water }\end{array}$ & (29) \\
\hline 5. & Qurș Kuhruba & Jaryān al dam (haemostatic) & $5-7 \mathrm{gm}$ & Oral & (29) \\
\hline 6. & Kushta Marjān Sada & $\begin{array}{l}\text { Du 'f -al-Dimāgh (Cerebrasthenia), Nazla } \\
\text { o Zukām (cold and catarrh), Su 'āl } \\
\text { (cough), Diq al-Nafas (bronchial asthma), } \\
\text { Jarayān (spermatorrhoea), Du 'f al- } \\
\text { Ishtihā ( loss of appetite) }\end{array}$ & $60-250 \mathrm{mg}$ & $\begin{array}{l}\text { Orally with appropriate } \\
\text { Badriqa (vehicle) } \\
\text { such as butter }\end{array}$ & (29) \\
\hline 7. & Kushta Marjān Jawahār wala & $\begin{array}{l}\text { Du'f al-Qalb (Cardiac insufficiencies), } \\
\text { Du 'f al-Dimāgh (Cerebrasthenia), } \\
\text { Du 'f al- Kabid (hepatic insufficiency), } \\
\text { Chronic Cold, Jarayān al Mani } \\
\text { (spermatorrhea) }\end{array}$ & $30-60 \mathrm{mg}$ & $\begin{array}{l}\text { Oally with Khamīra } \\
\text { 'Gā'ozabān }\end{array}$ & (29) \\
\hline 8. & Mufarriḥ barid & $\begin{array}{l}\text { Mufarriḥ Qalb (Exlihirant of Heart), } \\
\text { Khafaqān (palpitation), Ikhtilāj } \\
\text { (fasciculation), Sadr-o-Duwār (vertigo and } \\
\text { giddiness) Musakkin ḥarārat (antipyretic) }\end{array}$ & $5-7 \mathrm{gm}$ & Orally & (29) \\
\hline 9 & Mufarrih Sheikhur Rais & $\begin{array}{l}\text { Du 'f al -Qalb (Cardiac insufficiencies), } \\
\text { Khafaqān (Palpitation), Hummā Diqqiyya } \\
\text { (Hectic Fever), Du 'f al- Am (General } \\
\text { debility), Muqawwī-i-A'd̄ā Ra '̄isa } \\
\text { (tonic for vital organs) }\end{array}$ & $3 \mathrm{gm}$ & Orally & (29) \\
\hline 10 & Mufarriḥ Motadil & $\begin{array}{l}\text { Muqawwīi-i-A'ḍā Ra 'īsa (tonic for vital } \\
\text { organs), Muhafiz Hārarat Ghāriziyya } \\
\text { (Protector of innate heat), Tahrīk-i-Bāh }\end{array}$ & $5-10 \mathrm{gm}$ & Orally with plain water & (29) \\
\hline
\end{tabular}




\begin{tabular}{|c|c|c|c|c|c|}
\hline & & $\begin{array}{l}\text { (Aphrodiasic), Mushtahi (appetizer), } \\
\text { Naf-i-Ishāl (Antidiarrhial), Amrāọ-i- Rahim } \\
\text { (Uterine Disease) }\end{array}$ & & & \\
\hline 11 & Mufarriḥ Yāqūtī & $\begin{array}{l}\text { Mufarriḥ wa Muqawwi Adha-i-Raisa, } \\
\text { (Exhilirant and tonic of vital organs), } \\
\text { Du 'f wa naqahat (Weakness), Mushtahi } \\
\text { (Appetizer), Naf-i-Ishāl (antidiarrhial), } \\
\text { Amrāọ-i- Rahim(Uterine Disease) }\end{array}$ & $5-10 \mathrm{gm}$ & Orally with water & (29) \\
\hline 12 & Yāqūtī Bārid & $\begin{array}{l}\text { Muqawwīi-i-A'ḍā Ra '̄̄sa (Tonic of vital } \\
\text { organs), Khafaqān (Palpitation), Wahshat } \\
\text { (Insanity) }\end{array}$ & $3-5 \mathrm{gm}$ & Orally with water & (29) \\
\hline 13 & Yāqūtī Sada & $\begin{array}{l}\text { Mufarriḥ wa Muqawwi Qalb (exhilirant } \\
\text { and tonic of heart), Khafaqān (Palpitation), } \\
\text { Wahshat (insanity), Mālankhūliya } \\
\text { (Melancholia) }\end{array}$ & 5-7 gm & Orally with water & (29) \\
\hline 14 & Yāqūtī Lūlvi & $\begin{array}{l}\text { Muqawwīi-i-A'ḍā Ra 'īsa (tonic for } \\
\text { Vital organs), Muqawwīi-i-Bāh (Aphrodisiac) }\end{array}$ & 5-7 gm & Orally with water & (29) \\
\hline
\end{tabular}

\section{Calcium as immunomodulator}

In Unani Medicine, Jawahārat (Gems and Jewels), Ma'daniyyāt (minerals), Hajariyyāt (stones), animal shells and horns are used to strengthen the defense. Yāqūt, Zamarrad, Marwārīd, Baiza Murg, Khar i- Mohra, Sadaf, Kuhruba, Yashab, Marjan etc. are ingredient of the many formulations for this purpose (30). There are more than 50 chemical elements in our body which are required for growth, repair and regulation of vital functions of the body. It is a major mineral element of the body comprising $1.5-2 \%$ of body weight of adult human (31). Calcium is vital in the functioning of our immune system. Depletion of tissue calcium not only leads to bacterial and viral infection but can be a general indicator of susceptibility to severe illness with higher mortality rate. When we become feverish, this warning of body releases calcium making this mineral available to assist our body to protect itself from an assault. Calcium acts like a beacon for our immune system. It surrounds foreign matter, marking it for other immune system players, such as phagocytes, to come and destroy (32). Conversely, phagocytes as mentioned above are key players in our immune system's ability to fight infection, are inhibited by depleted blood calcium (33). Thus if we use up our calcium or interrupt it's absorption or distribution, our immune suffers greatly (32). Calcium is instrumental in assisting our body to fight infectious diseases, as shown in multiple studies. The Department of Biochemistry, University of Toronto found that in several systems that preclude the stimulus-induced changes in $[\mathrm{Ca} 2+]$ results in obliteration of the subsequent physiological response, suggesting a causal relationship. Thus, calcium seems to play a central role in the activation of cells of the immune system
(34). In another study, it is clear that vitamin D has important roles in addition to its classic effects on calcium and bone homeostasis. Deficiency in vitamin D is associated with increased autoimmunity and an increased susceptibility to infection (35). The Journal of Leukocyte Biology reported that the bone marrow induced macrophages (white blood cells that function as an integral part of our immune system) were increased and more active when there was sufficient blood calcium (36). In Science, the researchers noted that when more calcium was used in the therapy, the body was able to fight Epstein-Barr virus more effectively (37). Calcium helps to mark the foreign invaders and trigger our immune system to attack (32).

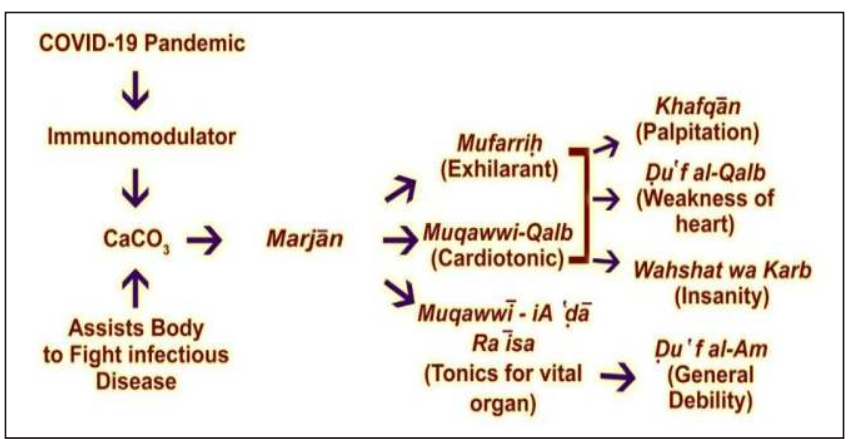

Fig. 1: Flowchart of Pharmacological actions of Marjãn (Coral).

Concept of Containment measures for susceptible host In Unani literature it has been mentioned that Tabī 'at (medicatrix naturae) is solely responsible for the capacity of the body to resist the disease and pathogen $(21,38)$. A well known Unani scholar, Rabban Tabri in his treatise Firdosul 
Hikmat, has mentioned that practically $\quad T a b \bar{l}$ 'at is regarded as an administrative power of the body. The function of administration of the body is accomplished by Tabì 'at by many powers called Quwā of the body like Quwā Tabīyya (Natural Faculties), Quwā Haywāniyya (Vital Power) and Quwā Nafsāniya (Mental faculty), Thus the main role of the Tabī 'at is to provide defense and immunity (Quwwt-iManaat) to the body (39). Each organ of the body works in coordination with each other to achieve the specific function of the body. This coordination between the organs is maintained by Tabī 'at with the help of Ala-i- Tabī 'at (their different tools). Here, the tool of Tabī 'at implies the relation to channels without which the function and process of Tabi 'at cannot occur. In relation to this statement Abu Sahl Maseehi in Kitabul Miāh says that Tabī 'at depends on support for the performing their function and process of the body (40).

Unani Medicine specially places emphasis on the Asbāb Sitta Daruriyya (six essential factors) i.e., Hawā (air), Mākūlāt-oMashrūbat (food and drink), Hārkat-o-Sukun Badani (bodily movement and repose), Hārkat-o-Sukun Nafsani (psychic movement and repose), Nawm-o-Yaqza (sleep and wakefulness) and Istifragh-o-Ihtibas (evacuation and retention). The lifestyle disorders like Depression, Coronary Heart Disease, Obesity etc., which are the major health burden of present time, can be successfully, economically and safely prevented by following the instructions with regard to these essential factors $(40,41)$. The concept of using organ and system specific tonics is a unique feature of Unani system of medicine. Unani physicians have described a number of drugs to strengthen and tone up the vital organs of the body and protect them to save against the possible harmful substances (40). Unani physicians have recommended improving the body immunity and strengthening the $T a b \bar{l}$ 'at by restoration of health and management of disease. For this purpose Unani scholars have mentioned various drugs under the headings of Muqawwiyāt and Mufarrihat such as Muqawwī-i-A 'dā' Ra'ìsa (tonics for vital organs), Muqawwī-i-Mida wa Ama (gastroahic and tonic for biliary tract), Muqawwīi-i-Ada Nafsaniyya (tonics for organs of the nervous system), Muqawwī-i-Qalb (cardiac tonics), Muqawwī-i-Jigar (liver tonics) etc. (21, 42). In Unani classical literature, they strongly recommend use of Muqawwiyāt and Mufarrihat during illness and for prevention of disease $(21,38,39)$ as well as in epidemics (42). Muqawwiyāt is non-toxic substances that have the ability to improve and maintain the health of the human body when used regularly over a long period of time. They tone up the internal organs and improve the body functions $(21,38,42)$. According to Unani Medicine, the disease doesn't occur in all individuals (44). The same air may be beneficial to someone and harmful to others (8). The same factor may provoke to be immune to someone while the same factors may trigger to be susceptible to others. Individuals with Hārr Ratab (hot and moist) temperament are at higher risk to invasion during epidemic in comparison to Bārid Yābis (cold and dry) temperament (5). Similarly the persons whose bodies are full of morbid matter are more susceptible in comparison to the person devoid of it (8). Presence of morbid matter or the increase in the Hārarat or Rutūbat or lessening Burūdat and Yubūsat in the body tissues provides conducive environment for the proliferation of Ufünat (infection) or in other words we can say it reduces the disease resisting capacity of the body. Hence the idea of Hifz-i-Mā Taqaddam advocated by Unani scholars during an epidemic is mainly centered around the axis of regimes rectifying the humoral imbalance and tries to keep the body in non-susceptible state $(5,46)$. Once the susceptibility of the disease no longer exists, either we don't contract the disease or even if contracted, the episode will be less virulent as the body is ready to counter any invasion of disease causing agents (19).

Epidemic containment measures mentioned by Unani scholars can be broadly divided into cause-centric and hostcentric. Host-centric method is applicable at individual level. It is aimed to strengthen the host defense. Rāzī mentioned that temperamentally Bārid Yābis (cold and dry) individuals rejoicing the advantage of health, when the danger of epidemic lurks around provided that appropriate preventive measures are taken to retain their Burūdat and Yubūsat (coldness and dryness). He also mentioned that Tajfif (desiccation) is an excellent approach to take care of temperamentally Hārr Ratab (hot and moist) individuals who often affected during epidemics $(5,45)$. Based on the perspective of susceptible host, several measures have been recommended to strengthen the host defense and to reduce the susceptibility towards the disease. It includes both pharmacological and non-pharmacological interventions. Based on concept of Tajfïf (desiccation), drug having Bārid Yābis (cold and dry) property such as coral may be recommended. According to Baghdadi and Baytār, Marjā̄ has intense property of desiccation $(26,27)$.

\section{DISCUSSION}

It is interesting to note that Unani physicians have emphasized the use of Marjān (Coral) as Mufarrih Qalb (Cardiac exhilarant) (24, 26, 27). Avicenna (Ibn Sinnā) says that it exhilarates the cardiac tissues Bil Khāșșa (characteristically) and Bil Tab' (naturally) through its Quwwat-i-Qabiza (retentive power) and Quwwt-i-Habisa (haemostatic power) (Sīnā, 1956). Coral is a source of $\mathrm{Ca}^{++}$ions (18). Metal ions such as $\mathrm{Ca}$ in the body are used to provide structural component, to serve as enzymatic co-factors and to mediate 
electron transportation. It also critically implicated in regulating both innate immune sensing of T-cells and host defense against invading pathogens. Nevertheless we are still in a primary stage of discovering immunological functions of ions and mechanistically understanding the role of these ions in immune regulation (47). Use of Marjan̄ in Unani Medicine suggests that pioneers of the system were well aware about the importance of metal ions, its source and its role in immunity. According to Baghdād̄̄, it has intense property of desiccation. Al Rāzī has mentioned that individuals with Bārid Yābis Mizāj (cold and dry temperament) may rejoice the more advantage of health, when the danger of epidemic lurks around provided that appropriate preventive measures are taken to retain their Burūdat and Yubūsat. He also mentioned that Tajfíf (desiccation) in an excellent prophylactic approach for the individuals having Hārr Rațab Mizāji (hot and moist temperamental) obligations who often suffer during epidemics (42, 45). As Marjān has intense property of desiccation, its use as prophylactic drug may be recommended to reduce the susceptibility of higher risk group having Hārr Rațab Mizāj (hot and moist temperament). The susceptibility of the disease may be lessened by employing the regimes such as desiccation of host by use of Marjan including all those which checks the humoral imbalance and keep the body in non-susceptible state. This may help to counter the strong waves of pandemic.

Considering calcium arguably the most important immunomodator; Marjān as it's principal source may be used as future medicine cabinet. Coral is an important source of new medicines being developed to treat cancer, arthritis, human bacterial infections, Alzheimer's disease, heart disease, viruses and other diseases (48). Since coral is stationery animals, may has evolved chemical defenses to protect themselves from predators. Scientists continue to research the medicinal potential of these substances. In the future, coral reef ecosystem could represent an increasingly important source of medicinal treatment, nutritional supplement, pesticides and other commercial products.

\section{CONCLUSION}

An effective measure of containment of spread of infection is to strengthen the host defense. Assessing calcium in the form of compound formulations of Marjan may help to strengthen the cardiac tissues by its desiccating nature. Its use in compound formulation form is epidemiologically relevant, immunologically effective, operationally feasible and socially acceptable. As coral, the tiny creatures adopt to thrive in oceanic waves; it gives human beings a lesson to design containment measures to survive in pandemic waves.

\section{FINANCIAL SUPPORTAND SPONSORSHIP} Nil

\section{CONFLICT OF INTEREST \\ Nil}

\section{ACKNOWLEDGMENT}

The authors are highly thankful to Director General, CCRUM, New Delhi, India for generating enthusiasm amongst the research workers for publishing more and more data available at the peripheral centers.

\section{REFERENCES}

1. Vellingiri, B., Jayaramayya, K., Iyer, M., Narayanasamy, A., Govindasamy, V. and et al, 2020. COVID-19: A promising cure for the global panic, Sci Total Environ [Published online 2020-April -4] Sci Total Environment.725:138277, doi.10.1016/j.scitotenv. 2020.1382772020,725, 138277

2. Nazli, T., Henna, R., Raheem, A., Kishore, J., 2020. Perceptions and Practices of adult population in response to SARS-CoV-2 Pandemic in india. J Epidem. Int. 5(2) 10-16. https:// orcid. Org/ 0000-0003-45153485

3. World Health Organization (WHO), 2021. Corona Virus Disease (COVID-19 Situation Report (COVID19) outbreak situation report-(accessed on $29^{\text {th }}$ July 2021), WHO Coronavirus (COVID-19) Dashboard | WHO Coronavirus (COVID-19) Dashboard With Vaccination Data

4. Government of India (GoI) COVID-19 Dashboard as on $28^{\text {th }}$ July 2021, 8:00 IST (GMT $+5: 30$ ), accessed on $29^{\text {th }}$ July 2021 2021, https://www.mygov.in/covid-19.

5. Rāzī, Z., 2008. Kitab al Hāwi. CCRUM, New Delhi, India. 15151-5

6. Sinaā, I., 2010. Al-Qānūn Fi'l Tibb. Idāra Kitabush Shifat,New Delhi, India. 1, 102-10, 1205-08.

7. Anonymous. 2012. Standard Unani Medical Terminology. CCRUM, New Delhi, India. 157.

8. Majūsī, I.A., 2010. Kāmil al-Sạna’a al-Tịbbiyya. Idāra Kitabush ShifāNew Delhi, India. 226-7.

9. Kabīruddīn, H.M., 2009. Hummayāt-e-Qānūn. Central Council for Research in Unani Medicine, New Delhi, India. 2, 39-47.

10. Khān, M.A., 2011. Aksīr-e-Azam [Urdu]. Idāra Kitabush Shifā, New Delhi, India. 916-19.

11. Tillu, G., Chaturvedi, S., Chopr,a A., Patwardhan, B., 2020. Public Health approach and Yoga for COVID-19 prophylaxis, J Altern Compliment med. 26, 360-4.

12. Rajkumar, R.P., 2020. Ayurveda and COVID-19 where psychoneuro immunology and the meaning response meet. Brain Behav Immun. 87, 8-9. 
13. Cooper, E.L., Hirabayashi, K., Stychar, K.V., Sammarco, P.W., 2014. Coral and their potential application to Integrative medicine, Evidence based complementary and alternative medicine. Article ID184959, 9 pages, https//dx.doi.org/10115/2014/184956.

14. Wali, A.F., Majid, S., Rasool, S., Shehada, S.B., Abdulkarim, S.K., Firdous, A., Beigh,S., Shakeel, S., Mushtaq, S., Akbar, I. et al, 2019. Natural products against Cancer: Review on phytochemicals from marine sources in preventing cancer. Saudi pharm Journ. 27, 767-777, https://doi.org/10.1016/j.jsps.2019.04013

15. Aslam, M., Tariq, M., Farhan, K.M., Ahmad, M.A., Jolly, R., Siddiqui, A., 2015. Quality control of a marine origin based Herbo-mineral Unani formulation. int $\mathrm{J}$ Pharm Sc and Drugs Res. 7(3), 275-278.

16. Leong, G.C., 1995. Certificate Physical and Human Geography. New Edition Oxford India. 80.

17. Abbas, A., Mustehasan., 2016. Adviya Haiwaniya. Islahi healthcare foundation. New Delhi, India. 25-27.

18. Lata, S., Biradar, R.S., 2015. Physico-chemical analysis of Praval Bhasam prepared by using Praval mool as raw material. Int $\mathrm{J}$ of Ayur and Herb Me. 5:4, 1954-1963. http://www.intersciencew.org.uk accessed on $9^{\text {th }}$ May 2021.

19. Itrat, M., Khān, T.N., Riaz, Z., Zulkifle, M., 2020. Epidemic containment measures in Unani medicine and their contemporary relevance. J Indian Sys Medicine [serial online] [accessed 2020 Sep 29]. 8, 84-90. Available from: http://www.joinsysmed.com/ text.asp?2020/8/2/84/294436

20. Usaiba, A.I., 1990. Uyunun Al Amba fi Tabaqat al Atibba. CCRUM, New Delhi, India. 698.

21. Nafīsi, A.B.U., 1934. Kulliyat e Nafīsi, (U Trans by Kabīruddīn). IKS, New Delhi, India. 1, 1959.

22. Tabasum, H., Ahmad, T., 2018. Principles and practice of cosmetic care in Unani Medicine. Educreation Publishing. New Delhi, India. V.

23. Narayanan, V., Pallewar, S., Mane, A., Bhargava, A., 2018. A Randomized, Volunteer, Pharmacokinetic Study Comparing Absorption and Bioavailability of Coral Calcium with Calcium Carbonate and Calcium Citrate Malate Supplements. European Journal of Pharmaceutical and Medical Research. 5341. https://www.researchgate.net/publication/329885143_ a_randomized_volunteer_pharmacokinetic_study_com paring_absorption_and_bioavailability_of_coral_calci um_with_calcium_carbonate_and_calcium_citrate_ma late_supplements
24. Ghanī, N., 2010. Khazainul Advia. IKS. New Delhi, India. 1283.

25. Sīnā, I., 1956. Kitab al Adwiyah al Qalbiyah, (U Trans by Latif HA). Iran society, Kolkata, India. 61.

26. Baytār, I., 2000. Kitab Jami al Mufridat li al-Adviya wa al-Aghziya. CCRUM, New Delhi, India. 1, 235.

27. Baghdadi, I.H., 2005.Kitab Al Mukhtarat (U Trans). CCRUM, New Delhi, India. 2, 82.

28. Hakeem, M.A., 1999. Bustanul Mufradat. Zafar Book Depot. Delhi, India. 92.

29. Rahmān, S.Z., 1991. Kitab al Murakkabāt. Publication Division, AMU, Aligarh, India. 74-77, 122-138, 174182.

30. Hafiz, A., 2010. Sana al Taklees. CCRUM, New Delhi, India. 36, 229.

31. Park, K., 2009. Textbook of Preventive and Social Medicine. Banarasidas Bhanot publishers, Jabalpur, India. 20, 537.

32. Holland, J., April 20, 2020. Calcium- arguably the most important mineral of our immune system. https://lakewoodacupunture.org/2020/04/20/calciumim munity

33. Tanaka, K., Usui, Y., Kojo, S., 2001. Role of serum components in the binding and phagocytosis of oxidatively damaged erythrocytes by autologous mouse macrophages. CMLS, Cell. Mol. Life Sci. 58, 1727-1733. https://doi.org/10.1007/PL00000811

34. Grinstein, S., Klip, A,. 1989. Calcium homeostasis and the activation of calcium channels in cells of the immune system. Bull NY Acad Med. 65(1), 69-79.

35. Aranow, C., 2011. Vitamin D and the immune system. $J$ Investig Med. 59(6), 881-886. doi:10.2310/ JIM.0b013e31821b8755

36. Faggioni, A., Zompetta, C., Grimaldi, S., Barile, G., Frati, L., Lazdins., 1986. J Calcium modulation activates Epstein Barr Virus Genome Latently Infected cells Science. June 20, 232(4757), 1554-6.

37. Jesse, T.M., Joel, A., Swanson. 2002. Calcium Spikes in Activated Macrophages during FC Gamma Receptor Mediated phagocytosis. J of Leuc Biology. 72, 677-684.

38. Hamdāni, S., 1998. Usool e Tib. National Council for Promotion of Urdu Language. Delhi, India. 41-42 327332 332-340 346-355 395-404.

39. Tabri, A.R., 2003. Firdousal Hikmat. Faisal Publications, Doeband, India. 128.

40. Anonymous, 2016a. Unani Medicine in India- An overview. CCRUM, MoAYUSH, GOI. New Delhi, India. 28 
41. Anonymous, 2016b. Unani System of Medicine the Science of Health and Healing. CCRUM, MoAYUSH, GOI. New Delhi, India. 1522313639.

42. Lone, A.H., Ahmad, T., Anwar, M., Sofi, G.H., Imam, H., 2012. Perception of Health Promotion In Unani Medicine. Med Jo Islamic World Academy of Sci. 20 (1), $1-5$.

43. Samarqandi ANU, 2009. Al Asbāb al Alamāt (Urdu transltion by Kabeeruddin) Mualijāt Sharah Asbāb. I KS, New Delhi, India. 4, 499-515.

44. Rushd, I., 2017. Kitab-al-Kulliyyat. Maktaba Daniyal, Lahore, Pakistan. 368-70.
45. Rāzì, Z., 1991. Kitāb al-Mansurī. CCRUM, New Delhi, India. 175-77.

46. Jurjānì, I., 2010. Dhakhīra Khawārizm Shahì. Idāra Kitabush Shifa- New Delhi, India. 1, 6-23.

47. Wang, C., Zhang, R.W., Wein, Xiaoming., Lv, Mengze., Jiang, Z., 2020. Metalloimmunoly: The metal ion controlled immunity, Adv in Immun. 145, 187-241 http:/doi.org/10.1016/bs.ai.2019.11.007

48. National Oceanic and Atmospheric Administration, What does coral have to do with medicine? https://oceanservice.noaa.gov/facts/coral_medicine.ht ml accessed on 9th May 2021. 